\title{
Urban ecological life in a metropolitan area-an insight from Satoyama conservation activities in the Greater Tokyo Area
}

\author{
Naomi Shimpo ${ }^{1,2}$ (1) \\ Received: 31 December 2020 / Revised: 24 September 2021 / Accepted: 1 October 2021 / Published online: 23 October 2021 \\ (c) International Consortium of Landscape and Ecological Engineering 2021
}

\begin{abstract}
Urban residents need to live in an ecologically sustainable way to mitigate and adapt to climate change. To discuss the model of urban ecological life, this paper focused on Satoyama landscapes and reviewed academic articles on the existing cases of Satoyama conservation by urban residents in the Greater Tokyo Area. We analyzed activities performed by participants, benefits to participants, and targeted and achieved ecosystems. Several findings were obtained from the review of published literature. First, the participants were mainly elderly men aged 60 years or older, who were not necessarily local people and who were motivated mostly by the need to conserve nature and improve their health. People with intellectual disabilities also enjoyed the benefits of Satoyama woodland management. Second, participants tended to recognize benefits in terms of health promotion, social cohesion, recreation, and resource utilization, rather than landscape and biodiversity conservation. Third, there were different directions of Satoyama conservation from the perspectives of nature and humans. The broader ecosystem beyond each site was not necessarily considered in Satoyama conservation. These findings show the potential of, and the necessity for, attracting other urban residents by including various activities that consist of not only vegetation conservation but also communal events based on different preferences. There is also a need for balancing environmental and socio-economic perspectives, and the targeted ecosystem should be further explored in collaboration with experts in ecology and landscape planning to make urban ecological life feasible.
\end{abstract}

Keywords Green space conservation · Suburban areas · Participatory biodiversity conservation $\cdot$ Sustainable lifestyle

\section{Introduction}

As the effects of climate change are actualized in daily life in the form of extreme weather, urban residents must pursue ecologically sustainable living. The United Nations predicts that $68 \%$ of the global population will live in urban areas by 2050; this proportion is already at 55\% (UN 2018), which means that urban life will have a greater impact on the environment. Thus, an urban ecological life model that can be applied to any city worldwide is needed.

Satoyama (sato: village, yama: mountain, in Japanese) originally meant woodlands on hills or mountains near villages that were sources of fuelwood or fallen leaves, which

Naomi Shimpo

naomi_shimpo@awaji.ac.jp

1 University of Tsukuba, 1-1-1 Tennodai, Tsukuba, Ibaraki 3058572, Japan

2 Present Address: University of Hyogo, 954-2 Nojimatokiwa, Awaji, Hyogo 6561726, Japan were used as agricultural fertilizer; it is currently defined as a rural ecosystem composed of a mosaic of connected woodlands, grasslands, farmlands, ponds, and creeks according to a research group by the United Nations University and Ministry of Environment, Government of Japan (Okada 2017). It provides habitats for a wide variety of wild animals and plants, owing to intermediate disturbance from humans (Washitani 2001; Katoh et al. 2009). However, human intervention is necessary to maintain Satoyama, as was observed in Japan prior to its rapid economic growth (Takeuchi 2001). Woodlands, the principal component of Satoyama landscapes, were largely destroyed during the late 1960s as a result of rapid urbanization and abandoned following the loss of economic value after the energy revolution, which saw a shift from fuelwood to oil (Takeuchi 2001; Fukamachi et al. 2001; Ichikawa et al. 2006; Morimoto 2011). In the late 1980s, local movements for Satoyama conservation began (Kuramoto 2003). Citizen participation in Satoyama conservation is expected to rebuild coexistent relationships between humans and nature, instead of material prosperity 
and convenience (Shigematsu 1993). If the number of participants increases, the importance of Satoyama conservation may be recognized by politicians, leading to new and effective policies for their conservation (Shigematsu 1993). Additionally, recent global climate change has led to the simplification of crop plants and invasion by alien species (Jiao et al. 2019), resulting in the degradation of biodiversity and ecosystems in the entire Satoyama landscape. However, the direct causes of the current deterioration of Satoyama landscapes should be examined via the lenses of the changing lifestyles of urban residents, because these landscapes are formed as a result of human interaction with the nature.

As the relationship between humans and nature constantly changes, it is essential to seek modern productive relationships between the communities and Satoyama (Yokohari and Bolthouse 2011); for example, instead of fuelwood or charcoal, the production of renewable biomass energy is an effective use of harvested wood from Satoyama woodlands (Yokohari and Bolthouse 2011). Agroforestry may also be a new way of linking woodlands and farmlands in Satoyama landscapes (Kumar and Takeuchi 2009). Toward the revitalization and sustainable conservation of socio-ecological production landscapes and seascapes, the Satoyama Initiative was proposed by the United Nations University and the Ministry of the Environment of Japan (UNU-IAS and IGES 2018), which attracted attention outside Japan in pursuit of a sustainable lifestyle (Berglund et al. 2014; Kumar and Takeuchi 2009; Morimoto 2011). This initiative is expected to find a way of conservation suitable for modern society.

At the local level, urban residents and farmers are important actors in Satoyama conservation (Kobori and Primack 2003); for example, non-profit organizations (NPOs) work on the restoration of Satoyama landscapes (Takeuchi 2001). A survey by the Ministry of the Environment, Japan, held from 1999 to 2001 showed that many Satoyama activity sites were in suburban areas, particularly within a $50 \mathrm{~km}$ radius of the three largest cities: Tokyo, Osaka, and Nagoya (MOE 2001). In 2018, 4,209 citizen associations worked on woodland conservation in Japan (NPO Morizukuri Forum 2019). There were also volunteer groups engaged in Satoyama conservation, including paddy fields and farmland with consent by farmers, who are also landowners. Although no exact statistics can be found, Tokyo Prefecture introduced at least 20 groups working in conservation areas designated by the prefecture (Bureau of Environment n.d.). There were likely more groups in the Greater Tokyo Area, that is, Tokyo, Saitama, Chiba, Kanagawa, Ibaraki, Tochigi, Gunma, and Yamanashi prefectures.

To build an urban lifestyle model committed to Satoyama landscapes, it is necessary to first determine how residents can be involved in conservation activities. While a certain workload is required for the maintenance of an ecosystem, the time individuals can spend on the activities varies based on various factors, such as age (Takatori et al. 2017). Their motivations for conservation also differ from nature-oriented to human-oriented (Dearborn and Kark 2010). It is necessary to sort out the current findings into separate case studies in terms of participants' attribution and motivation to determine who among the urban residents are already engaged in ecological activities and what measures should be taken to involve other candidates in the future.

The benefits of participating in Satoyama conservation should also be clarified to promote a lifestyle that includes such activities. For example, engagement in green space conservation helps the environment and human health. Loss of contact with nature has negatively affected people's physical and mental health (Soga and Gaston 2016). Recovering the connection between humans and nature in urban life is necessary and can be realized in the Satoyama remaining in urban peripheries. Japan has the largest aging population in the world, and health support for the elderly is a major challenge for its society. The population is encouraged to be as healthy as possible on their own as the budget for the medical support decreases with the decline in the total population. If elderly citizens maintain their physical and mental health through physical activity and finding their role in the society in Satoyama conservation, municipalities can reduce their expenses (Shigematsu 1993). Furthermore, the emerging work style involving the utilization of internet may reduce the time spent on commuting to the workplace. If urban workers spend their spare time in Satoyama conservation, both ecosystems and humans will enjoy the benefits.

Urban ecological life requires proper ecological perspectives and knowledge. To maintain Satoyama landscapes, local citizens engaging in their conservation need appropriate knowledge of the ecosystem (Tsuchiya et al. 2014). Formerly, Satoyama conservation activities in Tokyo focused on preserving the symbolic species of its landscapes and expanding it to the surrounding environment (Kuramoto 2003). However, because of the complex ecosystems consisting of secondary forests, croplands, and settlements, adaptive management is required (Hiratsuka et al. 2020). First, the target state of an ecosystem should be set by Satoyama activity groups, not only from bioecological perspectives but also for social welfare benefits, and an activity plan must then be developed (Matsumura 2007). After the planned work is conducted, the results should be examined to obtain feedback for further planning by the participants themselves (Matsumura 2007). By repeating this process, an ideal ecosystem and lasting activities can be realized. This process is yet rarely observed (Matsumura 2007). The difficulty lies in identifying a person with proper knowledge to evaluate the results of conservation activities, and if the motivation of volunteers is not necessarily ecological conservation, their intended use for Satoyama might not produce an ecologically ideal state (Matsumura 2007). Bottom-up approaches should 
be conducted in conjunction with specialists from various fields (Fukamachi 2020) who possess ecological knowledge about the ecosystems (Indrawan et al. 2014), while balancing the motivation of the participants (Matsumura 2007).

This paper reviews activities on Satoyama conservation by urban residents in the Greater Tokyo Area, Japan, and discusses a model of urban ecological life based on the aforementioned discussion points. This review aims to answer the following key questions: (1) Which urban residents participate in what kind of activities for Satoyama conservation? (2) What are the benefits to the participants? (3) What ecosystem is targeted by activities and what are the results? Based on answers to the questions mentioned above and by grasping the current picture of Satoyama conservation in the outskirts of a mega-city, a future model of urban ecological life will be discussed.

\section{Materials and methods}

This qualitative review covers Satoyama conservation activities conducted by residents in the Greater Tokyo area. Peer-reviewed articles, including those contained in the bulletins of universities, were collected using two academic search engines: "CiNii" for papers written in Japanese, and "Web of Science" (topic search) for those written in English. The keyword combinations used included: the name of a prefecture in the Greater Tokyo Area (Tokyo, Saitama, Chiba, Kanagawa, Ibaraki, Tochigi, Gunma or Yamanashi), "Satoyama," and the words "conservation, management, or activity." This search was conducted between 8 and 30th December 2020. Articles that did not focus on conservation by residents were excluded. A total of 27 articles were included in the analysis; 24 were in Japanese and 3 were in English.

Information related to the three research questions was extracted from the articles. First, information on the purpose, frequency, and location of activities, attributes, and motivation of participants was extracted to get the characteristics and commitment of participants to Satoyama conservation. Second, the description on the benefits of Satoyama activities to the participants was collected. Third, information on the targeted biota set by the participants and the actual ecosystems brought by the activities were collected. Table 1 lists the categorized information extracted from each article. The findings in each category were then discussed.

The Greater Tokyo Area is the largest metropolitan area in Japan with abundant green spaces that are under pressure owing to urban development. Approximately $56 \%$ of the area was composed of farmland, forests, and nature or urban parks in 2013 (Statistics Bureau of Japan 2015). $57 \%$ of Tokyo, the most populated prefecture, was composed of green spaces (Statistics Bureau of Japan 2015).
The population of the Greater Tokyo Area has increased constantly since 1975 and accounted for $35.1 \%$ of the total population of Japan in 2019, although this trend is expected to be reversed by 2020 (MLIT 2020). Focusing on each type of green space, the urban park area increased by $11 \%$ from 2008 to 2018 (MLIT 2020). Meanwhile, the area and number of allotment garden sites increased to approximately 160 sites and 160 ha by 2017 and then decreased slightly by 2019 (MLIT 2020). However, the forest area decreased by 156.64 $\mathrm{km}^{2}(0.9 \%)$ from 2007 to 2017 (MAFF n.d.a), and the farmland area also decreased by $359.00 \mathrm{~km}^{2}(6 \%)$ (Statistics of Japan 2010, 2020). Thus, conservation of green spaces is needed in the Greater Tokyo area to counter development pressure.

\section{Findings}

\section{Variation in activities and participants in Satoyama conservation}

Although "Satoyama" spatially comprises various natural and agricultural land uses combined with human settlements, majority of the Satoyama activities in the published articles were conducted in woodlands, sometimes combined with agricultural fields (Table 2). In addition to these physical characteristics, different purposes for Satoyama were identified (Table 3), which are likely to affect the ecosystems and participants' motivation. Even though some articles investigated multiple cases and thus simple comparison of article numbers is inappropriate, the results indicate that Satoyama conservation activities tend to be grouped into woodland management and conservation of green space, scenery, and biodiversity.

The types of activities conducted in Satoyama also varied. For example, participants, including people with intellectual disabilities, engage mainly in thinning of trees and undergrowth, picking up garbage, and/or collecting fallen leaves for compost as part of woodland management. Basically, the function of productive forests is lost, but there are some cases of producing and selling compost made from collected leaves (Tanaka et al. 2012; Tanaka 2015, 2016). Another approach to sustainable forest use includes forest cemeteries (Kim 2009). In some cases, urban residents also enjoy communal activities, such as cooking, handcrafting, and walking in the forest (Nakajima and Furuya 2004b; Tatsui and Fujii 2006; Karasaki et al. 2010; Kieninger et al. 2012; Kobayashi et al. 2017). Additionally, surveys on rare species that are important for Satoyama ecosystems are also conducted as part of Satoyama conservation (Nakajima and Furuya 2004b; Takayama 2010; Kobayashi et al. 2017; Kobayashi and Abe 2018). Providing environmental programs to nearby schools or visitors is another option (Nakajima and Furuya 2004b; 
Table 1 Retrieved articles with relevant information

\begin{tabular}{|c|c|c|c|c|c|}
\hline Article & $\begin{array}{l}\text { Purpose, frequency, and } \\
\text { location of activities }\end{array}$ & $\begin{array}{l}\text { Attribution of } \\
\text { participants }\end{array}$ & $\begin{array}{l}\text { Motivation of } \\
\text { participants }\end{array}$ & $\begin{array}{l}\text { Benefit to } \\
\text { participant }\end{array}$ & $\begin{array}{l}\text { Targeted } \\
\text { ecosystems and } \\
\text { results }\end{array}$ \\
\hline Hamaguchi et al. (2010) & $\mathrm{X}$ & $\mathrm{X}$ & & & $\mathrm{X}$ \\
\hline Ichikawa et al. (2010) & $\mathrm{X}$ & & & & \\
\hline Jingu et al. (2018) & $\mathrm{X}$ & & & & $X$ \\
\hline Karasaki et al. (2010) & $\mathrm{X}$ & $\mathrm{X}$ & & & \\
\hline Kieninger et al. (2012) & $\mathrm{X}$ & & $\mathrm{X}$ & & \\
\hline Kikuchi (2012) & $\mathrm{X}$ & $\mathrm{X}$ & & & \\
\hline $\operatorname{Kim}(2009)$ & $\mathrm{X}$ & $\mathrm{X}$ & $\mathrm{X}$ & $\mathrm{X}$ & \\
\hline Kobayashi and Abe (2018) & $\mathrm{X}$ & & & & $X$ \\
\hline Kobayashi et al. (2017) & $\mathrm{X}$ & $\mathrm{X}$ & & & $X$ \\
\hline Kojima et al. (2017) & $\mathrm{X}$ & $\mathrm{X}$ & & & \\
\hline Kouno (2019) & $\mathrm{X}$ & & & $\mathrm{X}$ & \\
\hline Matsumoto et al. (2011) & $\mathrm{X}$ & $\mathrm{X}$ & & & $\mathrm{X}$ \\
\hline Nakajima and Furuya (2004a) & & $\mathrm{X}$ & & & \\
\hline Nakajima and Furuya (2004b) & $\mathrm{X}$ & $\mathrm{X}$ & & & \\
\hline Nakamura et al. (2005) & $\mathrm{X}$ & $\mathrm{X}$ & $\mathrm{X}$ & $\mathrm{X}$ & $X$ \\
\hline Okayama et al. (2017) & $\mathrm{X}$ & & & & $\mathrm{X}$ \\
\hline Suzuki and Suzuki (2009) & $\mathrm{X}$ & $\mathrm{X}$ & $\mathrm{X}$ & & $\mathrm{X}$ \\
\hline Tanaka et al. (2012) & $\mathrm{X}$ & & & & $\mathrm{X}$ \\
\hline Takayama (2010) & $\mathrm{X}$ & $\mathrm{X}$ & & & \\
\hline Tanaka (2015) & $\mathrm{X}$ & $\mathrm{X}$ & & & \\
\hline Tanaka (2016) & $\mathrm{X}$ & & & & \\
\hline Tatsui and Fujii (2006) & $\mathrm{X}$ & & $\mathrm{X}$ & $\mathrm{X}$ & $\mathrm{X}$ \\
\hline Terada et al. (2010) & $\mathrm{X}$ & $\mathrm{X}$ & & & $X$ \\
\hline Tsuchiya et al. (2013) & & & & & $\mathrm{X}$ \\
\hline Tsuchiya et al. (2014) & & $\mathrm{X}$ & $\mathrm{X}$ & & \\
\hline Yamaguchi and Mitsuhashi (2007) & $\mathrm{X}$ & & & $\mathrm{X}$ & \\
\hline Yoshimura and Minowa (2004) & $\mathrm{X}$ & $\mathrm{X}$ & $\mathrm{X}$ & $\mathrm{X}$ & \\
\hline
\end{tabular}

Karasaki et al. 2010; Kieninger et al. 2012; Kobayashi et al. 2017; Kojima et al. 2017). Thus, there are a variety of Satoyama conservation activities, mainly in woodlands, which can benefit both nature and humans.

For associations that set regular working days, the frequency of collective activities varies from several days to 12.5 days a month (Nakamura et al. 2005; Ichikawa et al. 2006; Matsumoto et al. 2011; Kouno 2019). The activities are usually volunteer-based; however, one of the associations engages in woodland management with a fee (Matsumoto et al. 2011). An exception is the NPO, which is entrusted with the management of the Satoyama area as an urban park. This NPO maintains the vegetation almost every other day (Jingu et al. 2018). A compost factory operated by a municipality also pays a fee for collecting fallen leaves from woodlands, and participants can earn approximately 89,200 to 122,800 yen in the winter season depending on the amount of leaves collected (Tanaka 2015). These facts show gradation from leisure to professional work.
Some common attributes of participants, for example, age, sex, and place of residence, were identified in the articles. Most of the individuals participating in Satoyama activities were retired individuals aged 60 years or older. This aging demographic characteristic is raised as a challenge toward sustainability of activities in general (Kim 2009; Takayama 2010; Matsumoto et al. 2011; Tsuchiya et al. 2014; Tanaka 2015; Kouno 2019). A single-day program on woodland maintenance attracted people mostly in their 20s (Yoshimura and Minowa 2004). Tsuchiya et al. (2014) showed that more than $80 \%$ of the association members of the Satoyama woodlands were male. Although the proportion of female participants is small, they play a significant role in communal events (Karasaki et al. 2010). The distance between the participants' houses and their working sites varied from 0 to $20 \mathrm{~km}$ (Nakajima and Furuya 2004a), meaning that they were not necessarily local people. Karasaki et al. (2010) reported a similar finding in their case study. Additionally, there is a case in which a Satoyama field commonly 
Table 2 Fields of Satoyama activities identified in the retrieved articles

\begin{tabular}{|c|c|c|c|c|c|c|}
\hline Article & Woodland & Grassland & Paddy field & Crop field & Waterside & Others \\
\hline Hamaguchi et al. (2010) & $\mathrm{X}$ & $\mathrm{X}$ & & & $\mathrm{X}$ & $X$ \\
\hline Ichikawa et al. (2010) & $\mathrm{X}$ & & & $\mathrm{X}$ & $\mathrm{X}$ & \\
\hline Jingu et al. (2018) & $\mathrm{X}$ & & & & & \\
\hline Karasaki et al. (2010) & $\mathrm{X}$ & & & $\mathrm{X}$ & & \\
\hline Kieninger et al. (2012) & & & $\mathrm{X}$ & & & \\
\hline Kikuchi (2012) & $\mathrm{X}$ & & $\mathrm{X}$ & $X$ & $\mathrm{X}$ & $X$ \\
\hline Kim (2009) & $X$ & & & & & \\
\hline Kobayashi and Abe (2018) & & & $\mathrm{X}$ & & & \\
\hline Kobayashi et al. (2017) & $\mathrm{X}$ & & & & & \\
\hline Kojima et al. (2017) & $\mathrm{X}$ & & & & $\mathrm{X}$ & $\mathrm{X}$ \\
\hline Kouno (2019) & $X$ & $X$ & $\mathrm{X}$ & & & \\
\hline Matsumoto et al. (2011) & $X$ & & & & & \\
\hline Nakajima and Furuya (2004a) & $X$ & & $X$ & & $\mathrm{X}$ & \\
\hline Nakajima and Furuya (2004b) & $\mathrm{X}$ & & $\mathrm{X}$ & & $X$ & \\
\hline Nakamura et al. (2005) & $\mathrm{X}$ & & & & & \\
\hline Okayama et al. (2017) & $\mathrm{X}$ & & & & & \\
\hline Suzuki and Suzuki (2009) & $\mathrm{X}$ & & & & & \\
\hline Tanaka et al. (2012) & $\mathrm{X}$ & & & & & \\
\hline Takayama (2010) & $\mathrm{X}$ & & & & & \\
\hline Tanaka (2015) & $\mathrm{X}$ & & & & & \\
\hline Tanaka (2016) & $\mathrm{X}$ & & & & & \\
\hline Tatsui and Fujii (2006) & $X$ & & & $X$ & & \\
\hline Terada et al. (2010) & $X$ & & & & & \\
\hline Tsuchiya et al. (2013) & $\mathrm{X}$ & & & & & \\
\hline Tsuchiya et al. (2014) & $\mathrm{X}$ & & & & & \\
\hline Yamaguchi and Mitsuhashi (2007) & $\mathrm{X}$ & & $\mathrm{X}$ & & & \\
\hline Yoshimura and Minowa (2004) & $\mathrm{X}$ & & & & & \\
\hline
\end{tabular}

Table 3 Number of articles mentioning the purpose for the Satoyama activities

\begin{tabular}{lc}
\hline Purposes of Satoyama activities & $\begin{array}{l}\text { Number } \\
\text { of articles }\end{array}$ \\
\hline Woodland management & 11 \\
Green space conservation & 7 \\
Scenic conservation & 6 \\
Biodiversity conservation & 6 \\
Community revitalization & 5 \\
Environmental education & 4 \\
Resource utilization & 4 \\
Promotion of agriculture & 3 \\
Recreation & 2 \\
Health promotion & 1 \\
Social cohesion & 1 \\
\hline
\end{tabular}

used by neighbors became part of a university campus. In this case, there were conflicts between the university staff sometimes and the neighbors, when the neighbors claimed to have rights to use the field, took resources, such as bamboo sprouts, and threw garbage. Eventually, the university staff started engaging in Satoyama conservation and excluding neighbors from the activities (Suzuki and Suzuki 2009). Thus, depending on conditions, such as land tenure, groups of participants may possess stronger characteristics of thematic communities rather than local communities.

The motivations for participating in Satoyama conservation are not limited to nature conservation (Table 4). Suzuki and Suzuki (2009) introduced a case in which participants prioritized biodiversity. However, other cases showed different results; for example, tenants of rice terraces were attached to the landscape and were willing to take action to preserve the terraces, while the activities were also important for recreation (Kieninger et al. 2012). Tatsui and Fujii (2006) found that the prioritized reasons for participation in Satoyama conservation were: "I like nature (33\%)," and "I want to do farming (25\%)." Thus, personal feelings toward Satoyama landscapes are a strong motivation. In the case of the use of Satoyama for woodland burial, participants' views on life and death and irrelevance to religion were prioritized and their contribution to planting followed as reasons of registering for 
Table 4 Principal motivations of participants in Satoyama conservation listed in the retrieved articles

\begin{tabular}{|c|c|}
\hline Article & Motivations \\
\hline Kieninger et al. (2012) & $\begin{array}{l}\text { Attachment to rice terraces, being close to nature, taking part in the preservation association, preservation of } \\
\text { rice terraces, recreation }\end{array}$ \\
\hline $\operatorname{Kim}(2009)^{*}$ & $\begin{array}{l}\text { Attractiveness of returning to nature, no need for maintenance of graves, no relevance to religion, contribution } \\
\text { to planting and Satoyama conservation }\end{array}$ \\
\hline Nakamura et al. $(2005)^{* *}$ & $\begin{array}{l}\text { Providing opportunities for contact with nature, health promotion, physical function improvement and social } \\
\text { interaction }\end{array}$ \\
\hline Suzuki and Suzuki (2009) & Biodiversity conservation \\
\hline Tatsui and Fujii (2006) & Attachment to nature, the will to farm \\
\hline Tsuchiya et al. (2014) $)^{* * *}$ & Environmental conservation, social interaction \\
\hline Yoshimura and Minowa (2004) & Exercise in nature, environmental conservation in terms of water resource, woodlands, and biodiversity \\
\hline
\end{tabular}

the membership. (Kim 2009). Furthermore, the staff of a facility for the intellectually disabled also expected to provide opportunities for "contact with nature," "health promotion," "physical function improvement," and "social interaction" to the facility users through Satoyama conservation activities (Nakamura et al. 2005). These facts mean that the reasons for joining Satoyama conservation vary, depending on the activities or the attributes of participants. On the other hand, Tatsui and Fujii (2006) elucidated that people who originally wanted to do farming recognized the importance of plants in Satoyama landscapes after joining the activities. This suggests that whatever the original motivation is, their interests in ecosystems may increase through Satoyama conservation activities. Even though participants with an interest in the natural environment have a higher level of ecological knowledge (Tsuchiya et al. 2014), it is necessary to involve people with broader interests to secure enough workload to maintain Satoyama landscapes.

\section{Benefits to participants}

Some articles mentioned the benefits of participating in Satoyama conservation (Table 5). The enjoyment of activities was addressed in several studies. For example, Kim (2009) and Tatsui and Fujii (2006) found that participants enjoyed social interaction through Satoyama conservation activities. Touching nature, eating food, and watching plants are also fun elements for participants (Kim 2009; Yoshimura and Minowa 2004). Additionally, refreshed feelings and a sense of fulfillment stimulate participants to engage in Satoyama conservation (Yoshimura and Minowa 2004). The impact on health improvement for people with intellectual disabilities in a facility was shown. Even though the facility residents could not obtain work opportunities to get salaries as expected, Satoyama activities, such as thinning of trees improved their physical abilities and stabilized their minds (Nakamura et al. 2005). However, Kouno (2019) found that participants could be either relaxed or stressed after Satoyama conservation activities. Although the reasons for these differences were not discussed, it might mean that Satoyama

Table 5 Benefits of Satoyama conservation to participants as listed in the retrieved articles

\begin{tabular}{|c|c|}
\hline Article & Benefits \\
\hline Kim (2009) & $\begin{array}{l}\text { Enjoying social interaction, convenience of visiting the grave and participate in gatherings at the same time, } \\
\text { enjoying being in touch with nature, eating local food }\end{array}$ \\
\hline Kouno (2019) & Possibility of being relaxed \\
\hline Nakamura et al. (2005) & $\begin{array}{l}\text { Improvement of physical conditions, such as a good sleep, appetite and digestion, improvement of physical } \\
\text { strength, stabilization of mental condition }\end{array}$ \\
\hline Tatsui and Fujii (2006) & Enjoying social interaction \\
\hline Yamaguchi and Mitsuhashi (2007) & $\begin{array}{l}\text { Increased interest in Satoyama landscapes } \\
* \text { Results of environmental education program for junior high school students }\end{array}$ \\
\hline Yoshimura and Minowa (2004) & $\begin{array}{l}\text { Refreshed feeling after working, enjoying eating and plant watching during a break, a sense of fulfillment to } \\
\text { see maintained woodlands }\end{array}$ \\
\hline
\end{tabular}


conservation may not only relax people but can sometimes induce nervousness, depending on the condition. In any case, benefits were clearly observed in multiple studies. By receiving the above-mentioned benefits from Satoyama conservation activities, urban residents could join further activities and deepen their interests in Satoyama conservation, as Yamaguchi and Mitsuhashi (2007) showed that junior high school students began to take an interest in Satoyama after undertaking woodland management as an environmental education program.

\section{Targeted ecosystems and results of activities}

Satoyama conservation can be nature- or human-oriented. Jingu et al. (2018) introduced a case that sets a different target vegetation and management strategy in each plot; for example, ever green forests as potential natural vegetation and oak forests (Quercus serrata and Quercus acutissima) with different intervals of thinning, grassland, and bush. There are places where visitors can experience nature as well. In this case, the balance of preservation of vegetation changes caused by natural succession, intentional protection of specific species, and active use of landscapes by humans was considered. Another case that focused too much on preservation eventually led to abandoned and degraded vegetation (Suzuki and Suzuki 2009). On the contrary, Matsumoto et al. (2011) and Okayama et al. (2017) showed examples that aimed to provide clear views inside the woodlands for recreation and beauty. By thinning trees, the working conditions to further maintain vegetation in woodlands became better, while the inhabitant species also changed because the sunlight could now reach below the tree crowns (Nakamura et al. 2005). Participants in another case had a clearer intention to thin trees that were easy to cut down and left tall trees in terms of esthetics (Kobayashi et al. 2017). Even though the function of productive woodlands was lost in many cases, one case investigated by Tanaka et al. (2012) obtained two certifications from the Forest Stewardship Council related to economic values: one was the forest management certification, which ensures sustainable economic viability, while the forest is being managed properly to preserve biodiversity and benefits for local people; the other was the chain of custody certification, which confirms that the products are environmentally and socially responsible (Forest Stewardship Council n.d.). Thus, the ideal state of ecosystems pursued through Satoyama conservation depends on whether the prioritization of each activity is valued for biota or humans.

Actors are one of the factors influencing the state of ecosystems. Tsuchiya et al. (2013) found that the height of the dwarf bamboo (Pleioblastus chino (Franch. et Sav.) Makino) is higher when private landowners maintain woodlands than when municipalities or citizen groups do. Hamaguchi et al.
(2010) also reported that in the process of selecting landscapes to be conserved and indicator species to evaluate landscapes, residents listed the landscape components that they wanted to conserve from cultural perspectives, such as their memorable places or the identity of their city. Thus, the possible management and preferable landscapes change, depending on the actors.

Associations for Satoyama working on their own sites do not necessarily consider connectivity to other sites. Kobayashi and Abe (2018) investigated the genetic diversity of Japanese brown frogs (Rana japonica Günther) at five sites where citizen associations engage in the conservation of the environment. As a result, different degrees of genetic diversity were observed in the sites, which might have been caused by habitat division. Takayama (2010) found that approximately $50 \%$ of the associations for environmental conservation in the Tone River Basin consider the continuity of the environment in the basin. Meanwhile, some associations, particularly in the downstream areas, have the capacity and intention to expand their activity sites. Others have less motivation or resources to work in a broader area. The necessity for the cooperation of associations in different areas to maintain and improve ecosystems is indicated from these facts.

\section{Discussion}

The articles reviewed in this study showed a rich variety of activities and participants' motivation for Satoyama conservation, which can attract more people to start an urban ecological life. When linking purpose with the benefits of Satoyama conservation activities, participants may not get direct benefits from conservation itself but may recognize ones in terms of health promotion, social cohesion, recreation, and resource utilization (e.g., composting) (Fig. 1). The majority of benefits identified in this review were indeed not from the direct results of conservation but from the immediate effects of the activities themselves. The goal is green space and biodiversity conservation; however, more recognizable benefits over the short term should be emphasized to appeal to urban residents to participate in Satoyama conservation.

Aging participants were mentioned as a problem in many cases throughout this review. Satoyama conservation can provide opportunities for the elderly to maintain and improve their physical and mental health so that they can continue to work. However, the involvement of the younger generation is essential for sustaining long-term activities. As this review found that participants in their 20s preferred a single-day program, attempts should be made to increase casual participants because young people are busy with their job and family lives, in general, making 
Fig. 1 Three types of the purposes of Satoyama activities based on direct benefits to residents

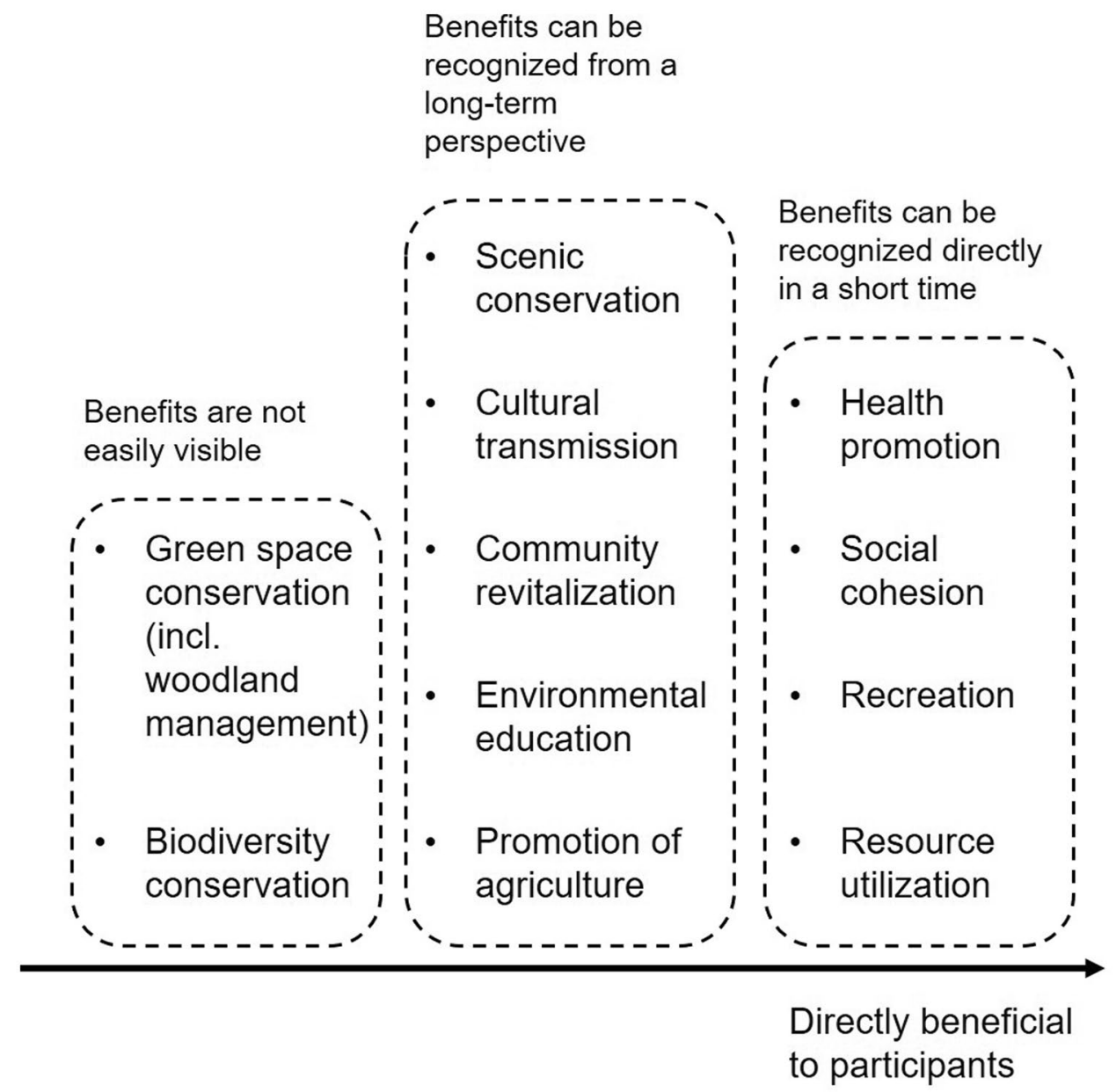

it difficult to commit to long-term membership. Generally, volunteers supported natural resource management with different motivations depending on the frequency of participation (Takase et al. 2019). Respecting various ways of participation is key to continuously attracting urban residents. Nakajima and Furuya (2005) also showed that university students participated in green space conservation within $2 \mathrm{~km}$ of their place of residence. Active promotion and invitation should be planned to involve younger generations based on this accessibility condition.

Considering the gender balance, increasing female participants is another option to involve newcomers. Satoyama can be a place for conducting various activities, from vegetation management to recreational events. It was shown that women play an active role in events, such as cooking and handcrafting. By planning these events combined with regular activities, more urban residents, including women, would be integrated into ecosystem management. Furthermore, people with intellectual disabilities can enjoy the benefits of Satoyama woodland management in terms of health improvement. The studies indicate that more diverse urban residents can lead a life that benefits both nature and humans by participating in Satoyama activities.

Socio-economic aspects are important for the feasibility of urban ecological life. The sustainable development goals aim to balance three dimensions: economic, social, and environmental development (UN n.d.). This review found that, in some cases, participants in Satoyama woodland management are earning money. If municipalities or other stakeholders, such as landowners can pay a fee for Satoyama conservation or if the participants can sell products and gain profit, not only environmental but also socio-economic benefits would be brought to the local areas. The economic benefits may not support an individual's life, but this "minor subsistence" can bring emotional value, such as enjoyment (Matsui 1998), which can be an incentive to continue Satoyama activities. Moreover, the established personal networks would enrich participants' lives. In terms of social empowerment, Satoyama activities can also provide professional skills. Current agricultural policies support collaboration between agriculpeople with disabilities in vegetable and fruit production is often featured, yet some cases utilize a Satoyama field, as ture and social welfare (MAFF n.d.b). The involvement of 
Nakamura et al. (2005) showed. The evaluation of the social and economic value of Satoyama conservation is needed for an urban ecological life to be widely accepted.

Regarding ecological aspects, the reviewed articles did not contain much information on the targeted ecosystems. One possible reason for this is that the articles were retrieved only when descriptions of citizen activities were included, presenting a limitation of this review. Articles that reported on detailed studies of the biota of Satoyama landscapes were identified, for example, Iwachido et al. (2020). The ecosystems may be sustained by urban residents, although the articles did not mention who maintained them and how. In any case, further analysis is needed to link citizen activities and ecosystems. The limited results in this review show that the targeted and achieved ecosystems vary from nature-oriented to human-oriented, depending on the case. It was also found that the division of habitats might influence the genetic diversity of wildlife. Furthermore, this review showed that "Satoyama" might be understood as just woodlands, as about half the papers treated management of woodland without other components, such as grasslands, farmlands, ponds, and creeks. Therefore, the appropriate balance of management types should be discussed further and on a broader scale.

\section{Conclusion}

This paper reviewed studies on Satoyama conservation by urban residents in the Greater Tokyo Area to obtain hints on promoting urban ecological life. The findings related to the key questions are: (1) The people who engaged in Satoyama activities were mainly elderly men in their 60 s or older who were not necessarily local residents. Their motivations varied and were not limited to ecological perspectives. (2) Participants tended to recognize benefits in terms of health promotion, social cohesion, recreation, and resource utilization, rather than conservation of landscapes and biodiversity. (3) There are different directions for Satoyama conservation from the perspectives of nature and humans. The broader scale of the ecosystem at each site is not necessarily considered in Satoyama conservation.

To promote an urban ecological life, including Satoyama activities, to various people living in cities, further analysis of the attractiveness of the activities and appropriate management of ecosystems is required. Specifically, the preferred activities for different urban residents must be determined, especially for young or female candidates. Additionally, more active collaboration among experts in landscape ecology and planning is essential to balance nature and human values and to provide implications for policies. As Tsuchiya et al. (2013) argued, multiple management actors are needed.
This qualitative review only covered a limited number of cases found in a mega-city and its surrounding areas. In addition to climate change, the risk of infectious diseases, such as COVID-19, affects urban life throughout the world. The realization of ecological and healthy living with an adequate understanding of local conditions is required urgently to compensate for the vulnerability of our society. Therefore, further review of cases in other areas should be conducted soon to theorize the way forward for urban ecological life and apply it to other cities with different sizes and land-use patterns.

\section{Declarations}

Conflict of interest The author has no conflicts of interest to declare that are relevant to the content of this article.

\section{References}

Berglund BE, Kitagawa J, Lagerås P, Nakamura K, Sasaki N, Yasuda Y (2014) Traditional farming landscapes for sustainable living in Scandinavia and Japan: global revival through the Satoyama initiative. Ambio 43(5):559-578. https://doi.org/10.1007/ s13280-014-0499-6

Buereau of Environment-Tokyo Metropolitan Government (n.d.) Introduction of volunteer groups of conservation areas (Hozenchiiki volunteer no shokai), https://www.kankyo.metro. tokyo.lg.jp/nature/volunteer/kyodo/volunteer/conservation/index. html. Accessed 7 June 2021

Dearborn DC, Kark S (2010) Motivations for conserving urban biodiversity. Conserv Biol 24(2):432-440. https://doi.org/10.1111/j. 1523-1739.2009.01328.x

Forest Stewardship Council (n.d.) Standards-forest management certification/chain of custody certification. https://fsc.org/en. Accessed 31 Dec 2020

Fukamachi K (2020) Building resilient socio-ecological systems in Japan: Satoyama examples from Shiga Prefecture. Ecosyst Serv 46:101187. https://doi.org/10.1016/j.ecoser.2020.101187

Fukamachi K, Oku H, Nakashizuka T (2001) The change of a satoyama landscape and its causality in Kamiseya, Kyoto Prefecture, Japan between 1970 and 1995. Landsc Ecol 16:703-717

Hamaguchi T, Aoki Y, Ishizaki A, Oguchi T, Kajii K, Koike F, Suzuki H, Higuchi K, Maruyama K, Miwa N, Moriue Y (2010) Biodiversity mapping by citizens based on an indicator species survey in suburban Chigasaki City. Jpn. J Conserv Ecol 15(2):297-307. https://doi.org/10.18960/hozen.15.2 297

Hiratsuka M, Hatakeyama K, Ohkubo T, Takeuchi D (2020) Dynamics of secondary forest and its perspective under the satoyama system in Saitama prefecture, Japan. J for Res. https://doi.org/10.1080/ 13416979.2020.1719573

Ichikawa K, Okubo N, Okubo S, Takeuchi K (2006) Transition of the satoyama landscape in the urban fringe of the Tokyo metropolitan area from 1880 to 2001. Landsc Urban Plan 78(4):398-410. https://doi.org/10.1016/j.landurbplan.2005.12.001

Ichikawa T, Ichikawa A, Urakawa R (2010) Composting of forest leaf litter in Satoyama preservation activities : changes in chemical and biological characteristics of forest leaf litter with difference in composting years and the effects on plant growth. Japan J Forest Environ 52(1):11-18. https://doi.org/10.18922/jjfe.52.1_11 
Indrawan M, Yabe M, Nomura H, Harrison R (2014) Deconstructing satoyama-the socio-ecological landscape in Japan. Ecol Eng 64:77-84. https://doi.org/10.1016/j.ecoleng.2013.12.038

Iwachido Y, Uchida K, Ushimaru A, Yokota S, Sasaki T (2020) Nature-oriented park use of satoyama ecosystems can enhance biodiversity conservation in urbanized landscapes. Landsc Ecol Eng 16:163-172. https://doi.org/10.1007/s11355-020-00413-y

Jiao Y, Ding Y, Zha Z, Okuro T (2019) Crises of biodiversity and ecosystem services in satoyama landscape of Japan: a review on the role of management. Sustainability 11(2):454

Jingu S, Take M, Sakata K, Ito T (2018) Study on management of a farm forest affected by change to recreational use as the Ushiku Nature Sanctuary. J Jpn Inst Landsc Architect 81(5):703-708. https://doi.org/10.5632/jila.81.703

Karasaki T, Yasunaka S, Kinoshita I (2010) Communication-gap issues in conservation activities among stakeholders in the practice of Satochi (domestic woodlands and farmlands). J Jpn Inst Landsc Architect 73(5):667-670. https://doi.org/10.5632/ jila.73.667

Katoh K, Sakai S, Takahashi T (2009) Factors maintaining species diversity in satoyama, a traditional agricultural landscape of Japan. Biol Conserv 142(9):1930-1936. https://doi.org/10.1016/j. biocon.2009.02.030

Kieninger PR, Penker M, Yamaji E (2012) Esthetic and spiritual values motivating collective action for the conservation of cultural landscape - a case study of rice terraces in Japan. Renew Agr Food Syst 28(4):364-379

Kikuchi T (2012) The commodification of rurality in the Jike Area, Yokohama City, the Tokyo Metropolitan Fringe. Kankoukagakukenkyu 5:23-33

Kim Y (2009) Future issues of afforested burial grounds as perceived by the afforested burial membership. Bull Tokyo Univ for 121:117-148

Kobayashi S, Abe S (2018) Genetic structure and gene flow of the Japanese brown frog. Jpn J Conserv Ecol 23(2):245-256. https:// doi.org/10.18960/hozen.23.2_245

Kobayashi K, Terada T, Yamamoto H (2017) Characteristic of woody biomass production by citizen satoyama maintenance groups in peri-urban Tokyo. J Jpn Inst Landsc Architect 80(5):637-640. https://doi.org/10.5632/jila.80.637

Kobori H, Primack RB (2003) Participatory conservation approaches for satoyama, the traditional forest and agricultural landscape of Japan. Ambio 32(4):307-311. https://doi.org/10.1579/0044-744732.4.307

Kojima S, Hattori T, Tanaka N, Machida R, Aso M (2017) Landscape perception of the children who live in the Satoyama-area which locate in the city suburbs based on "Kisawa-Hakkei selecting project.” J Jpn Inst Landsc Architect 80(5):575-578. https://doi.org/ $10.5632 /$ jila. 80.575

Kouno T (2019) Attempt of the verification of psychological effect by green space conservation activities. Int J Hum Cult Stud 2019(29):522-525. https://doi.org/10.9748/hcs.2019.522

Kumar MB, Takeuchi K (2009) Agroforestry in the Western Ghats of peninsular India and the satoyama landscapes of Japan: a comparison of two sustainable land use systems. Sustain Sci 4:215-232. https://doi.org/10.1007/s11625-009-0086-0

Kuramoto N (2003) Citizen conservation of Satoyama landscapes. In: Takeuchi K, Brown RD, Washitani I, Tsunekawa A, Yokohari M (eds) Satoyama: the traditional rural landscape of Japan. Springer, Tokyo, pp 23-35

MAFF (n.d.a) Proportion on forest area by prefecture (Todoufukenbetsu shinrinritsu jinkourinritsu). https://www.rinya.maff.go.jp/j/ keikaku/genkyou/index2.html. Accessed 30 Dec 2020

MAFF (n.d.b) Promotion of collaboration in agriculture and social welfare (Noufukurenkei no suishin). https://www.maff.go.jp/j/ nousin/kouryu/kourei.html. Accessed 31 Dec 2020
Matsui K (1998) The world of minor subsistence: labour, nature and the body in the field of folk (Maina sabusisutansu no sekai: Minzokusekai ni okeru roudou, shizen, shintai). In: Shinohara T (ed) Skills of folk (Minzoku no gijutsu). Asakura Publishing, Tokyo, pp 247-268

Matsumoto R, Yokohari M, Terada T, Yamamoto H (2011) The amount of harvestable woody biomass from suburban satoyamas by local citizen groups. J Jpn Inst Landsc Architect 74(5):707-710. https:// doi.org/10.5632/jila.74.707

Matsumura M (2007) Resisting the affect of the politics of ecology on "Satoyama" conservation volunteers: an alternative conservation design proposed by local people through their research on their local environments. J Environ Sociol 13:143-157

MLIT (2020) Annual report on the development of the Greater Tokyo Area 2019 (Reiwagannendo shutokenseibi ni kansuru nenjihoukoku). https://www.mlit.go.jp/report/press/content/001347631.pdf. Accessed 30 Dec 2020

MOE (2001) Intermediate report: Survey and analysis on SatochiSatoyama in Japan (Nihon no Satochi-Satoyama no chosa bunseki ni tsuite). http://www.env.go.jp/nature/satoyama/chukan.html. Accessed 29 Dec 2020

Morimoto Y (2011) What is Satoyama? Points for discussion on its future direction. Landsc Ecol Eng 7:163-171. https://doi.org/10. 1007/s11355-010-0120-5

Nakajima T, Furuya K (2004a) A study on the relation of the year of Satoyama activities to be formed to transition of open-space area in northern part of Chiba Prefecture. Pap Environ Inf Sci 18:49-54. https://doi.org/10.11492/ceispapers.ceis 18.0.49.0

Nakajima T, Furuya K (2004b) A Study on the Satoyama image toward survived open-spaces expected by participants for civic Satoyama management activity in northern part of Chiba Prefecture. J Jpn Inst Landsc Architect 67(5):653-658. https://doi.org/10.5632/jila. 67.653

Nakajima T, Furuya K (2005) A study on the young people's thinking process until leading to belong to the open-space conservation activity by students. Pap Environ Inf Sci 19:151-156. https://doi. org/10.11492/ceispapers.ceis19.0.151.0

Nakamura Y, Furuya K, Akasaka M (2005) Research on condition of the using forest "Satoyama" of social welfare institutions for mentally handicapped persons in metropolis Tokyo. Tech Bull Fac Horticult Chiba Univ 59:39-45

NPO Morizukuri Forum (2019) Results of survey on forest management activities 2018 (Shinrin zukuri katsudo ni tsuiteno jittai chosa Heisei 30 nen chosa syukei kekka). https://www.morid ukuri.jp/wp/wp-content/uploads/2019/03/H30_moridukuri_survey_report_190329.pdf. Accessed 29 Dec 2020

Okada W (2017) Origin of and change in the concept of Satoyamain history of forest policy. J for Econ 63(1):58-68

Okayama N, Tanaka N, Honda K, Matsumoto R (2017) A study on landscapes with experience based activities preferred by visitors in rural Satoyama in Japan. J Jpn for Soc 99(5):202-209. https:// doi.org/10.4005/jjfs. 99.202

Shigematsu T (1993) New coexistence of Satoyama and humans (Satoyama to hito tono atarashii kyosei). In: Ishii M, Ueda K, Shigematsu T (eds) Conserve nature of Satoyama (Satoyama no shizen wo mamoru). Tsukiji Shokan, Tokyo, pp 103-142

Soga M, Gaston KJ (2016) Extinction of experience: the loss of human-nature interactions. Front Ecol Environ 14(2):94-101. https://doi.org/10.1002/fee.1225

Statistics Bureau of Japan (2015) Statistics of Japan 2015: chapter 1 land and climate (Nihon no toukei 2015: Dai 1 syou kokudo kisyou). http://www.stat.go.jp/data/nihon/back15/01.html. Accessed 30 Dec 2020

Statistics of Japan (2010) Statistics on crops 2009. https://www.e-stat. go.jp/stat-search/files?page $=1 \&$ layout $=$ datalist $\&$ toukei $=00500$ $215 \&$ tstat $=000001013427 \&$ cycle $=7 \&$ year $=20090 \&$ month $=0 \&$ 
tclass $1=000001032270 \&$ tclass $2=000001032271 \&$ tclass $3=00000$ 1037074. Accessed 30 Dec 2020

Statistics of Japan (2020) Statistics on crops 2019. https://www.e-stat. go.jp/stat-search/files?page $=1 \&$ layout $=$ datalist $\&$ toukei $=00500$ $215 \&$ tstat $=000001013427 \&$ cycle $=7 \&$ year $=20190 \&$ month $=0 \&$ tclass $1=000001032270 \&$ tclass $2=000001032271 \&$ tclass $3=00000$ 1137629. Accessed 30 Dec 2020

Suzuki K, Suzuki R (2009) Exploring the sustainability of an on-campus green belt as a local commons. Int J Tourism Sci 2:85-93

Takase Y, Hadi AA, Furuya K (2019) The Relationship between volunteer motivations and variation in frequency of participation in conservation activities. Environ Manage 63:32-45. https://doi.org/ 10.1007/s00267-018-1106-6

Takatori C, Hasegawa Y, Fujiwara N, Shimizu H, Miyawaki M (2017) A research on management plan of secondary forest based on landscape preference and labor accounts - a case study of Fujimaki-Cho, Nagoya City. J City Plan Inst Jpn 52(3):1232-1239. https://doi.org/10.11361/journalcpij.52.1232

Takayama K (2010) Study on the existing conditions, problems and issues of citizen's group of environmental protection and management within the extended Tone River basin: to establish regional inter organizational ties. Univ Bull Chiba Inst Sci 3:161-175

Takeuchi K (2001) Nature conservation strategies for the "SATOYAMA" and "SATOCHI", habitats for secondary nature in Japan. Glob Environ Res 5(2):193-198

Tanaka M (2015) Actual acquisition of fallen-leaves in the "Midori Center" of Motegi-Town, Tochigi Prefecuture. J Jpn Inst Landsc Architect 78(5):731-734. https://doi.org/10.5632/jila.78.731

Tanaka M (2016) The actual acquisition of felling the bamboo and the use in the "Midori Center" of Motegi-Town, Tochigi Prefecuture. Landsc Res Jpn Online 9:83-90. https://doi.org/10.5632/jilao nline.9.83

Tanaka M, Shiratori R, Sakurai R, Sakai H (2012) Improvement and transformation to production forest of countryside forest by NPO. J Jpn for Eng Soc 27(3):179-183. https://doi.org/10.18945/jjfes. KJ00008160815

Tatsui M, Fujii E (2006) Effect of Satoyama preservation activity by civic group on vegetation and participants' awareness. J Jpn Inst Landsc Architect 69(5):777-780. https://doi.org/10.5632/jila.69. 777
Terada T, Yokohari M, Bolthouse J, Matsumoto R (2010) A citizenbased maintenance scheme for conservation of suburban satoyamas based on the Forest Working Plan. J Rural Plan Assoc 29:179-184. https://doi.org/10.2750/arp.29.179

Tsuchiya K, Okuro T, Takeuchi K (2013) The combined effects of conservation policy and co-management alter the understory vegetation of urban woodlands: a case study in the Tama Hills area, Japan. Landsc Urban Plan 110:87-98. https://doi.org/10.1016/j. landurbplan.2012.10.013

Tsuchiya K, Aoyagi M, Okuro T, Takeuchi K (2014) The potential of, and threat to, the transfer of ecological knowledge in urban areas: the case of community-based woodland management in Tokyo, Japan. Ecol Soc 19(2):25. https://doi.org/10.5751/ ES-06369-190225

UN (2018) News: $68 \%$ of the world population projected to live in urban areas by 2050, says UN. https://www.un.org/development/ desa/en/news/population/2018-revision-of-world-urbanizationprospects.html. Accessed 29 Dec 2020

UN (n.d.) Social Development for Sustainable Development. https:// www.un.org/development/desa/dspd/2030agenda-sdgs.html. Accessed 31 Dec 2020

UNU-IAS, IGES (2018) Sustainable use of biodiversity in socio-ecological production landscapes and seascapes. Satoyama Initiative Thematic Review, vol 4:ii

Washitani I (2001) Traditional sustainable ecosystem "SATOYAMA" and biodiversity crisis in Japan: conservation ecological perspective. Glob Environ Res 5(2):119-133

Yamaguchi H, Mitsuhashi N (2007) A study on actual conditions and residents' consciousness of maintaining activities for SATOYAMA : four cases of maintaining group of SATOYAMA in Gunma Prefecture and Tochigi Prefecture. J Rural Plan 26:311316. https://doi.org/10.2750/arp.26.311

Yokohari M, Bolthouse J (2011) Keep it alive, don't freeze it: a conceptual perspective on the conservation of continuously evolving satoyama landscapes. Landsc Ecol Eng 7:207-216. https://doi. org/10.1007/s11355-010-0116-1

Yoshimura T, Minowa M (2004) Building social relations centered on citizens in utilizing SATOYAMA: a case of "ASAZA Project" in Kasumigaura watershed; situations and its significance. Bull Tokyo Univ for 111:1-24 